\title{
Integrating Building Physics and Performance Simulation in Architectural Curricula: A Collaborative Effort
}

\author{
Christiane Berger and Ardeshir Mahdavi \\ Department of Building Physics and Building Ecology, TU Wien, Austria
}

\begin{abstract}
This paper presents an effort toward integrating building physics and building performance simulation in architectural curricula. The main objective of this effort, which is undertaken within the framework of a project supported by the European Union (IMPAQT) is to initiate a paradigm shift toward a more integrative, peoplecentred, and technologically agile professional profile of young architects. The present contribution focuses on those curriculum features related to building technology and performance assessment. The building technology track is described in detail, along with its relationship to the curriculum's other thematic tracks. Specifically, we explain the structure and content of the building simulation course and its strategic position within the building performance track.
\end{abstract}

\section{Introduction}

\section{Motivation}

This paper reports on efforts toward improving architectural education in the framework of the project IMPAQT ("Integrative Multidisciplinary People-centred Architectural Qualification \& Training") supported within the ERASMUS+ Programme (EACEA, 2018; IMPAQT, 2018) of the European Union. The main objective of this project is to promote a paradigm shift toward a more integrative, multidisciplinary, peoplecentred, and technologically agile professional profile of young architects. Thus, specific attention is paid to integrate social, urban, human, and technological aspects in a number of courses within a new architectural curriculum.

As such, material related to building physics or building performance simulation is already included in most architectural curricula. However, the preparatory work (including a gap analysis) in the initial stage of the IMPAQT project points to a number of needs and challenges in this area. Efforts were made to address these challenges in the course of the project. Toward this end, engineering disciplines and human sciences, aided by information and communication technologies, were deployed in a context-sensitive manner to encounter the challenges associated with sustainable human settlements.
The main focus of the present paper concerns the sequence of the components of the building technology track within the proposed curriculum. This building technology track is explained in detail, along with its relationship to the curriculum's other thematic tracks. Specifically, we discuss the intellectual underpinnings of the structure and content of the building simulation course projected to acquire a special strategic position within the building performance track (Berger, 2018). The integration of thermal building performance simulation should enable architecture students to approach design, amongst other things, as an iterative process to balance energy and carbon reduction targets with indoor environmental quality objectives.

\section{Background}

The three-year project IMPAQT started in October 2017. Within this project two main objectives are pursued: On the one hand, the project focuses on the development of a five-year undergraduate architectural engineering program. On the other hand, life-long learning modules in three subject areas (including building ecology and building physics, human requirements and contemporary city) are designed for a continuing education program. A group of four European and six Egyptian academic and non-academic partners contribute to these tasks with various levels of involvement according to their fields of specialization (including architecture and urban design, structural and construction systems, building physics and building ecology, and human behaviour). This collaborative effort enriches the project work by complementing the curricula with different thematic strength (Berger, 2018).

\section{Structure}

The present work first gives a summary representation of the aforementioned gap analysis. Subsequently, we focus on the development of the architectural curricula. Moreover, the sequence of the components of the building technology track is explained in detail, along with its relationship to the curriculum's other thematic tracks. Specifically, the integration of thermal building performance simulation within the curriculum is discussed 


\section{Challenges in architectural education}

Prior to the development of the curriculum, a gap analysis of needs and shortcomings in architecture education was performed. This gap analysis explored and analysed views and opinions from both practitioners and academics of the current architecture education.

In order to obtain a comprehensive gap analysis, different instruments (including an online questionnaire and interviews of academics and practitioners) were developed and designed within the project IMPAQT team (Shehayeb et al., 2018a). Over a period of three months, about 110 students and faculty of multiple schools of different countries participated in the online questionnaire and about 30 practitioners and academics agreed to participate in an interview.

Table 1 shows a partial result of this gap analysis. It includes a selection of questions posed regarding potential shortcomings in existing educational programs in architecture together with respective responses by students and faculty members obtained via the aforementioned online questionnaire.

The results suggest that about $50 \%$ of the respondents see a major problem in the lack of awareness of advances in building technology, material science, and construction methods. Other expressed shortcomings relate to the lack of integration of design-support tools (such as environmental simulation or parametric design tools), inadequate learning environments and tools, as well as poor integration of theoretical courses in design studios. About $51 \%$ of the respondents identify the gap between theoretical knowledge and their application in design studios as a crucial problem. As such, they underline the importance of technology integration in design studies.

Further key shortcomings mentioned are insufficient information concerning the job market for architecture graduates as well as lack of clarity regarding the practical relevance of the academic studies for the real world challenges (estimated by $58 \%$ of the respondents as a major problem). In this context, a number of respondents propose to further emphasize the link between theory and real practice, for instance via field visits to ongoing project sites, participation in related working meetings and workshops, as well as interactions with practitioners in architecture, building construction, and aligned fields. In general, some respondents suggest, schools should put more emphasis on the kinds of professional profiles for their graduates that are practice-oriented and embody technical competence.

Furthermore, many respondents rate BIM (Building Information Modelling) knowledge and a connection to the real-world activity domain as important features they would introduce or change in current architecture education.

Another main problem is the students' wanting knowledge of essential building codes and standards in a number of countries. Thus, an improved integration of codes related to architecture and urbanism in the architecture education is necessary.
Table 1: Selected gap analysis questions and responses: major problem (black), neutral (grey), no problem (white) (derived based on information by Shehayeb et al. 2018a).

\begin{tabular}{|c|c|c|}
\hline & Selected questions & Responses \\
\hline Q1 & $\begin{array}{l}\text { Lack of technological } \\
\text { awareness }\end{array}$ & \\
\hline Q2 & $\begin{array}{l}\text { Theory-application } \\
\text { divide }\end{array}$ & 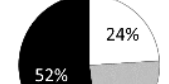 \\
\hline Q3 & $\begin{array}{l}\text { Lack of design-support } \\
\text { tools }\end{array}$ & \\
\hline Q4 & $\begin{array}{l}\text { Inadequate learning } \\
\text { environment / tools }\end{array}$ & \\
\hline Q5 & $\begin{array}{l}\text { Lack of course } \\
\text { integration }\end{array}$ & \\
\hline Q6 & $\begin{array}{l}\text { Ignorance regarding job } \\
\text { perspectives }\end{array}$ & \\
\hline Q7 & $\begin{array}{l}\text { Studies vs. real-world } \\
\text { market }\end{array}$ & \\
\hline
\end{tabular}

The gap analysis both confirmed and sharpened a number of pre-existing concerns about existing architectural education paradigms, thus motivating the project team toward concerted efforts to address some of these needs and shortcomings in the course of the present curriculum development.

\section{The general structure of the proposed curriculum}

The developed curriculum encompasses a five-year undergraduate program in architectural engineering that comprises 280 ECTS (i.e., 160 credit hours). Conceptually, the curriculum development was guided by the intention to ensure a multidisciplinary approach in the architecture education. In this context, Figure 1 illustrates a schematic concept of the curricular proposal and its five main thematic fields (including human sciences, history/ theory, urban planning, design and technology).

The concrete structure of the overall curriculum is captured in Table 2. Note that a preparatory first year provides general courses to acquire basic knowledge in social, urban, and technological subjects. Based upon this foundation, design studios, and theoretical modules are assigned to successive semesters of the studies. The last year of the program mainly focuses on the graduation project, which is conceived as a two-term design studio. 
Table 2: Structure of the overall curriculum (derived based on program description of the Nile University by Shehayeb et al. 2018b).

\begin{tabular}{|c|c|c|c|c|c|c|c|c|}
\hline & DESIGN STUDIO & $\begin{array}{c}\text { PEOPLE-CENTERED } \\
\text { THEORY }\end{array}$ & URBAN & $\begin{array}{l}\text { HISTORY OF } \\
\text { ARCHITECTURE }\end{array}$ & $\begin{array}{l}\text { BUILDING } \\
\text { TECHNOLOGY }\end{array}$ & $\begin{array}{l}\text { STRUCTURE \& } \\
\text { CONSTRUCTION }\end{array}$ & VISUAL & $\begin{array}{l}\text { LANGUAGE \& } \\
\text { ELECTIVES }\end{array}$ \\
\hline $\begin{array}{l}-{ }^{\text {SEMESTER } 1} \\
\simeq \\
\longleftarrow \\
\Psi \\
\succ_{\text {SEMESTER } 2}\end{array}$ & $\begin{array}{l}\text { Basis for Design } \\
\text { Drawing / Modelling }\end{array}$ & $\begin{array}{l}\text { Ethics } \\
\text { Contemporary City } \\
\text { Critical Thinking } \\
\text { Design Thinking I }\end{array}$ & $\begin{array}{l}\text { Selected Topics in } \\
\text { Humanities: } \\
\text { Environmental } \\
\text { Psychology }\end{array}$ & $\begin{array}{c}\text { History of } \\
\text { Architecture and } \\
\text { Urban Form I }\end{array}$ & $\begin{array}{c}\text { Probability \& } \\
\text { Statistics } \\
\\
\text { Natural Sciences: } \\
\text { Physics } \\
\text { Fundamentals }\end{array}$ & & $\begin{array}{c}\text { Computer \& } \\
\text { Information Skills }\end{array}$ & $\begin{array}{c}\text { Language I } \\
\text { Communication \& } \\
\text { Presentation Skills } \\
\text { Language II }\end{array}$ \\
\hline $\begin{array}{l}={ }^{\text {SEMESTER } 3} \\
\propto \\
\varangle \\
w \\
> \\
\\
\text { SEMESTER 4 }\end{array}$ & $\begin{array}{l}\text { Design Studio 1: } \\
\text { Residential } \\
\text { SITE } \\
\\
\text { Design Studio 2: } \\
\text { Public Realm } \\
\text { Street Design }\end{array}$ & $\begin{array}{l}\text { Selected Topics in } \\
\text { Social Sciences: } \\
\text { Research Methods }\end{array}$ & $\begin{array}{l}\text { Environmental } \\
\text { Behaviour Studies } \\
\\
\text { Dwelling and } \\
\text { Neighbourhood } \\
\text { Design }\end{array}$ & $\begin{array}{l}\text { History of } \\
\text { Architecture and } \\
\text { Urban Form II }\end{array}$ & Building physics I & $\begin{array}{l}\text { Construction I } \\
\text { Structure I }\end{array}$ & $\begin{array}{l}\text { Visual I } \\
\text { Visual II }\end{array}$ & $\begin{array}{l}\text { Writing Skills } \\
\text { Mapping } \\
\text { Preferences } \\
\text { Colour and Art } \\
\text { Architecture } \\
\text { Photography }\end{array}$ \\
\hline $\begin{array}{l}\equiv \\
\equiv \\
\propto \\
\propto \\
\varangle \\
w \\
>_{\text {SEMESTESTER } 6} 5\end{array}$ & $\begin{array}{c}\text { Design Studio 3: } \\
\text { Dwelling \& } \\
\text { neighbourhood design } \\
\text { Design Studio 4: } \\
\text { Facilities - Public } \\
\text { building } \\
\text { Public Space }\end{array}$ & $\begin{array}{l}\text { Advanced Design } \\
\text { Process }\end{array}$ & $\begin{array}{l}\text { Building Types } \\
\text { Places for People } \\
\text { People-centered } \\
\text { Urban Design }\end{array}$ & $\begin{array}{l}\text { Theory of } \\
\text { Architecture and } \\
\text { Urban Form I }\end{array}$ & $\begin{array}{l}\text { Building physics II } \\
\text { Building Systems } \\
\text { Integration }\end{array}$ & $\begin{array}{l}\text { Construction II } \\
\text { Structure II }\end{array}$ & & \\
\hline $\begin{array}{l}\geq \text { SEMESTER } 7 \\
\propto \\
\propto \\
\Psi \\
> \\
\\
\text { SEMESTER } 8\end{array}$ & $\begin{array}{c}\text { Design Studio 5: } \\
\text { Multi-Function Building } \\
\text { Ensemble } \\
\text { City Extension } \\
\\
\text { Design Studio 6: } \\
\text { Multi-Function Adaptive } \\
\text { Re-use } \\
\text { Urban Regeneration }\end{array}$ & & $\begin{array}{l}\text { Spatial and Urban } \\
\text { dynamics }\end{array}$ & $\begin{array}{l}\text { Theory of } \\
\text { Architecture and } \\
\text { Urban Form II }\end{array}$ & $\begin{array}{l}\text { Building } \\
\text { Performance } \\
\text { Computing }\end{array}$ & $\begin{array}{l}\text { Construction III } \\
\text { Structure III }\end{array}$ & $\begin{array}{l}\text { Building } \\
\text { Information } \\
\text { Modeling }\end{array}$ & $\begin{array}{l}\text { Sustainable } \\
\text { Heritage } \\
\text { Conservation } \\
\text { Landscape } \\
\text { architecture and } \\
\text { planning } \\
\text { Internship }\end{array}$ \\
\hline $\begin{array}{l}>\text { SEMESTER 9 } \\
\propto \\
\propto \\
\Psi \\
> \\
\text { SEMESTER 10 }\end{array}$ & $\begin{array}{l}\text { Graduation Project } 1 \\
\text { Graduation Project } 2\end{array}$ & & $\begin{array}{l}\text { Urban Planning } \\
\text { process: Planning } \\
\text { Cities for people }\end{array}$ & & & $\begin{array}{c}\text { Tender Doc } \\
\text { Site Supervision / } \\
\text { Project } \\
\text { Management }\end{array}$ & & $\begin{array}{l}\text { Sustainable } \\
\text { Development } \\
\text { Building Ecology } \\
\text { Urban Planning 2 } \\
\text { Informal Areas }\end{array}$ \\
\hline
\end{tabular}

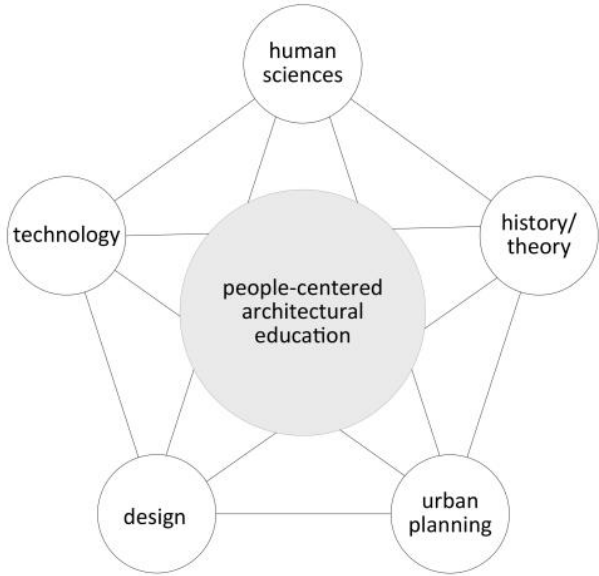

Figure 1: Schematic concept of architectural curricula.

\section{Building technology track}

Table 3 illustrates the general structure of the building technology track within the proposed curriculum. In the first preparatory year, basic science courses in probability, statistics, and physics are included. Building on this foundation, the mandatory courses "Building Physics I The thermal environment", "Building Physics II - The visual and acoustical environment", and "Building Systems Integration" follow. The course "Building Physics I - The thermal environment" provides an introduction to the fundamentals of the thermal aspects of building performance. Within the course "Building Physics II - The visual and acoustical environment", scientific foundations of building acoustics, room acoustics, daylighting, and illuminating engineering are discussed. An introduction to the fundamentals of 
buildings' technical systems (including HVAC systems, fire safety, water and wastewater infrastructure, electrical installations, transportation systems as well as building controls and automation) is given in the course "Building Systems Integration".

Thereafter, the course "Spatial and Urban Dynamics", which has a strong focus on urban environments' spatial and physical dynamics, is integrated. The building simulation course "Building Performance Computing" is situated in the fourth year. In the last year of studies, a number of electives provide possibilities to specialize in different thematic fields while pursuing the graduation project. For instance, the elective course "Building Ecology" provides an introduction to the description and evaluation of ecological performance of building components, systems, and structures.

Table 3: The general structure of the building technology track within the proposed new architecture curriculum.

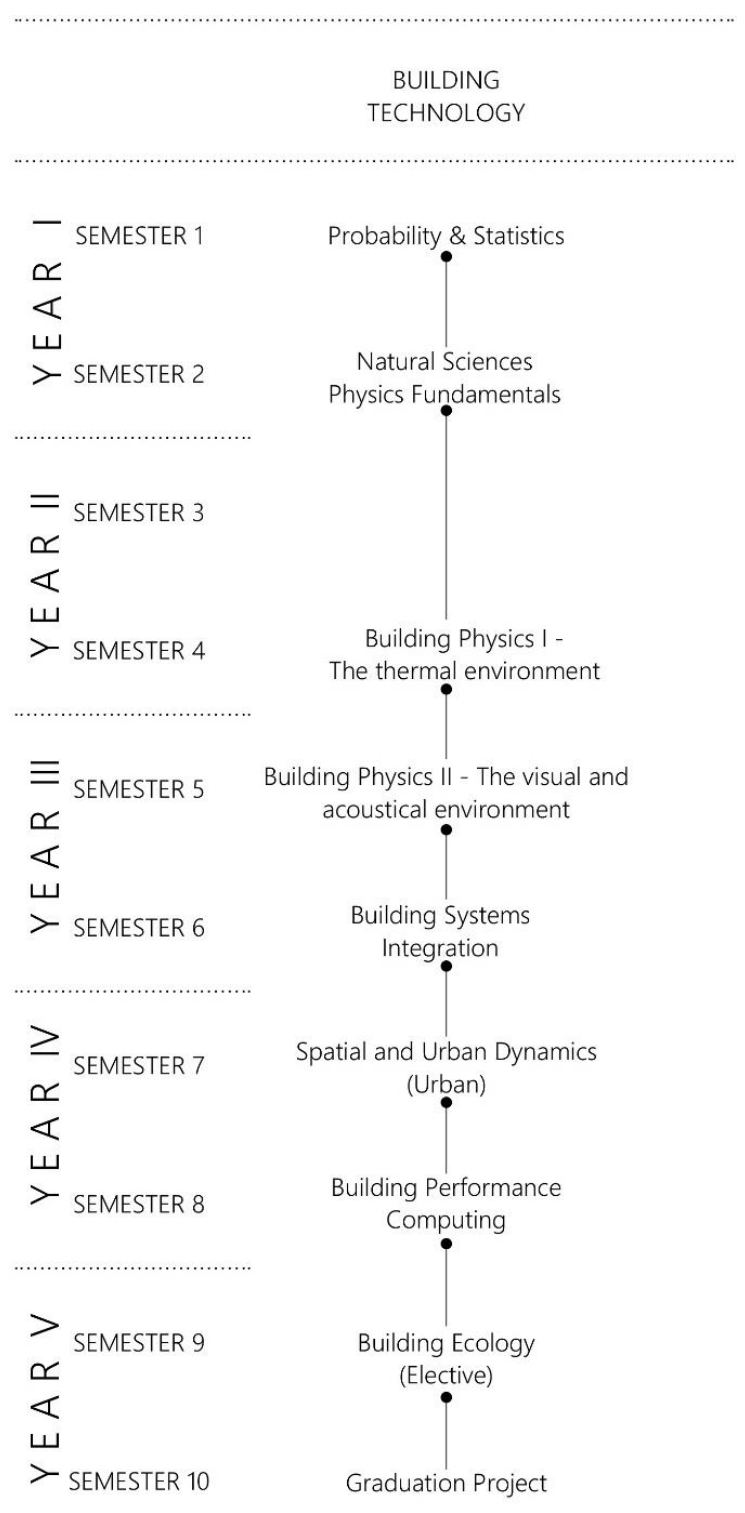

\section{The performance simulation integration}

Most stakeholders in the building design and delivery process agree that architectural design is not just about formal appearance or basic functional solutions. Rather, the professional community and building users alike appreciate the importance of buildings' performance and the quality and robustness of services they provide (Bleil de Souza and Knight, 2007). Likewise, there appears to exist a consensus in the professional community that the integrity and accountability of the design process can benefit from the deployment of computational design support tools in general and building performance simulation tools in particular.

Hence, the building performance simulation course has a special strategic position within the building technology track. Labelled "Building Performance Computing", this course gives an introduction to computational methods and applications for building performance assessment in advanced semesters. The course introduces thermal and visual modelling and design fundamentals of building performance simulation. In addition, case studies and assignments on the application of simulation in building design and operation are processed.

The design of this course is informed by our previous findings regarding the theory and practice of building performance simulation (Mahdavi, 2011; Mahdavi et al., 2003) as well as in teaching performance simulation within the framework of the graduate program "Building Science and Technology" at TU Vienna (BST, 2019). A key aspect of these experiences, shared by a large number of colleagues teaching simulation in other universities, is as follows: Proper understanding and competent use of building performance simulation tools necessitates a prior solid understanding of the foundations of building physics, building construction, and knowledge-based design principles. It is also important to nurture an intuitive sense of the involved physical phenomena in building behaviour, together with an overall order-ofmagnitude feeling for the values of commonly computed building performance indicators.

These insights explain in part the placement of the simulation course within the technology module of the curriculum. In our experience, the communicated preceding knowledge on physical processes and technical issues enables the students to reliably validate and properly interpret simulation results obtained. Hence, the implications of the design decisions (specifically, the choice of design options) on buildings' future thermal and visual performance (including its consequences for occupants' health, comfort, and satisfaction) can be systematically assessed and evaluated. This approach is believed to entail the potential to unlock the power of performance simulation as a tool to support an iterative approach to design process.

Within the developed curriculum, different approaches are used to integrate building performance simulation application in the overarching design methodology. Figure 2 provides a schematic depiction of the underlying conceptual approach. On the one hand, more "traditional" 
and frequently "single-domain" simulation engines such as EnergyPlus (EnergyPlus, 2018) and Radiance (Radiance, 2018) are adopted. These tools are seen as direct computational derivatives of first-principle physics-based models in building science, involving, for example, numeric heat and mass transfer. The associated scientific foundations are covered, as mentioned earlier, in the prior courses of the technology track. Thus, students are expected to be equipped with basic knowledge required for the proper understanding and interpretation of detailed thermal and visual performance analysis.

On the other hand, and in parallel, the complementary option of parametric modelling tools applications (with assorted disciplinary plug-ins) is pursued. There has been an increasing - and mostly promising - trend toward the deployment of parametric and generative tools both in architectural schools and in architectural practice. Parametric modelling tools and 3D modelling software such as Rhino (Rhino, 2018) and Revit (Revit, 2019), augmented with versatile technically oriented plug-ins such as Ladybug (Ladybug, 2018), Honeybee (Honeybee, 2018), etc. can support generative performance-based parametric design workflows. As such, they can offer a relatively simple usability level for connecting basic design models (building geometry and construction information) with analysis tool pertaining to domains such as energy and daylighting. Moreover, the overall increase of the digital literacy in the population of young students allows for the widespread use of programming tools and platforms such as platforms for visual scripting, for example, Grasshopper for Rhino (Grasshopper, 2018).

The above assertions have been validated, in part, by a recent study concerning the usability of building performance simulation environments within the design process (Bazafkan et al., 2019). The study identified, amongst other things, certain strengths associated with tools such as Ladybug (Ladybug, 2018) and Honeybee (Honeybee, 2018). The latter tools benefit from an easyto-use interoperability with geometry models generated in Rhino (Rhino, 2018). Moreover, the tools offer intuitive opportunities for the comparison and evaluation of different design alternatives: Users can obtain information regarding the impact of each design decision while working on the model. The design process (i.e., testing and documenting model manipulations) can also benefit from the tools' various visualisation possibilities. This two-fold approach facilitates, in our experience, a mode of simulation tool integration in the design development that has the potential to be both robust and intuitive. The students are thus encouraged to deploy analytical means already during the design development as such means reveal the different implications of design variations on buildings' performance.

\section{Ongoing implementation}

The realization of the proposed curriculum in the target university is a work in progress. Nonetheless, a brief mention of certain related issues may be of general interest to the academic communities keen on integrating building performance simulation in respective curricula.

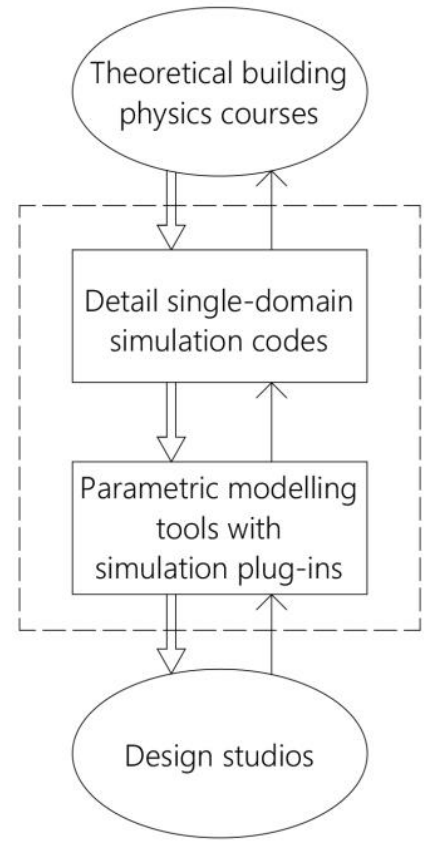

Figure 2: Integration of performance simulation applications as an integral component of knowledge-

based design methodology: single-domain tools computationally implement building physics process

knowledge, whereas augmented parametric tools transport the knowledge into the design exercise setting.

For instance, in the course of discussions with instructors of the foundational courses in mathematics and physics, the topical foci and depth of instruction was discussed, so as to address the later requirements for thorough understanding of the relevant energy and mass transfer processes simulated by computational tools. These topical foci (for instance, differential equations and their numeric solution methods) are not always covered in typical basic level science courses of most architecture and engineering schools.

A second important issue pertaining to the integration of technical courses in general and performance computing in particular concerns the relationship to design studios. In multiple discussions with the future instructors of these studies, cross references to technical topics (so-called vertical integration) was addressed.

The consensus emerging from these discussions highlights the significance of a kind of collaborative instructional spirit amongst the faculty: Whereas such a spirit cannot be formally mandated in all settings, efforts toward coordination of content, methods, and tools should be encouraged whenever possible. One concrete outcome of these discussions was the decision to explore the degree to which "light-weight" (e.g., web-based) computational tools could both support partial specific design tasks in the context of the design studios and prepare the students for the later dealings with more extensive, comprehensive, and challenging simulation environments. 


\section{Concluding remarks}

The present work reported on the ongoing efforts aiming at the realization of an integrated approach to innovative architectural undergraduate education. Based on a comprehensive research and a gap analysis of needs and shortcomings in architecture education, potential for improvement were identified. In order to address this potential, a new architectural engineering program is being developed by a number of experts in their fields of specialization within the framework of the project IMPAQT. We focused, in the present contribution, on describing the building technology track within the proposed undergraduate curriculum. Specifically, we outlined the underlying intellectual background as well as implementation specifics regarding the integration of (thermal and visual) building performance simulation in the curriculum in general and in conjunction with design teaching in particular.

Future steps within the project IMPAQT will involve the full implementation of the undergraduate architectural program at the School of Engineering at Nile University in Egypt. Moreover, the project will focus on a close feedback loop that informs both the technology track evolution as well as the design studio sequence toward a systematic outcome-based educational strategy.

\section{Acknowledgement}

The work presented in this paper was partially supported within the framework of the IMPAQT project ("Integrative Multidisciplinary People-centred Architectural Qualification \& Training") supported within the ERASMUS+ Programme of the European Union (project number 586437-EPP-1-2017-1-ATEPPKA2-CBHE-JP).

\section{References}

Bazafkan, E. et al. (2019). Usability and usefulness of non-conventional building performance simulation tools in architectural design processes. Proceedings of the twelfth international EnviBUILD Conference. Vienna (Austria), 219-226.

Berger, C. (2018). Master thesis. Department of Building Physics and Building Ecology, TU Wien.

Bleil de Souza, C. and Knight, I. (2007). Thermal performance simulation from an architectural design viewpoint. Proceedings of the tenth IBPSA conference. Beijing (China), 87-94.

BST (2019). https://www.tuwien.ac.at/de/lehre/ masterstudien/architektur/masterstudium_building_sc ience_and_technology/. Accessed 14.01.2019.

EACEA (2018). https://eacea.ec.europa.eu/node/ 2043_en. Accessed 21.11.2018.

EnergyPlus (2018). https://energyplus.net/. Accessed 17.01.2019.

Grasshopper for Rhino (2018). https://www. grasshopper3d.com. Accessed 17.01.2019.
Honeybee (2018). https://www.ladybug.tools/ honeybee.html. Accessed 17.01.2019.

IMPAQT (2018). http://www.impaqt.edu.eg/. Accessed 21.11.2018.

Ladybug (2018). https://www.ladybug.tools/ladybug. html. Accessed 17.01.2019.

Mahdavi, A. et al. (2003). An inquiry into the building performance simulation tools usage by architects in Austria. Proceedings of the eight IBPSA conference. Eindhoven (Netherlands), 777-784.

Mahdavi, A. (2011). The human dimension of building performance simulation. Proceedings of the twelfth IBPSA conference. Sydney (Australia), K16-K33.

Radiance (2018). https://www.radiance-online.org/. Accessed 17.01.2019.

Revit (2019). https://www.autodesk.com/products/revit. Accessed 17.01.2019.

Rhino (2018). https://www.rhino3d.com/download. Accessed 17.01.2019.

Shehayeb et al. (2018a). Gap Analysis IMPAQT project. Nile University. (internal document).

Shehayeb et al. (2018b). IMPAQT Program Description "Architecture \& Urban Design". Nile University. (internal document). 